\title{
EVALUASI KINERJA APARATUR PEMERINTAH \\ KOTA BANDAR LAMPUNG
}

\section{Yulia Neta}

\begin{abstract}
ABSTRAK
Pasal 12 Undang-Undang Nomor 43 Tahun 1999 tentang Perubahan Atas UndangUndang Nomor 8 Tahun 1974 Tentang Pokok-Pokok Kepegawaian diatur bahwa Manajemen Pegawai Negeri Sipil diarahkan untuk menjamin penyelenggaraan tugas pemerintahan dan pembangunan secara berdaya guna dan berhasil guna, dan untuk mewujudkan penyelenggaraan tugas pemerintah dan pembangunan, diperlukan Pegawai Negeri Sipil yang profesional, bertanggung jawab, jujur, dan adil melalui pembinaan yang dilaksanakan berdasarkan sistem prestasi kerja dan sistem karier yang dititik beratkan pada sistem prestasi kerja. Berdasarkan Hal tersebut Penelitian ini akan melihat bagaimana Kinerja Apatur Pemerintah Kota Bandar Lampung dalam menjalankan tugas yang dibebankan kepadanya, berdasarkan Kebijaksanaan manajemen Pegawai Negeri Sipil. Hasil penelitian menyimpulkan bahwa Pemerintah Kota Bandar Lampung, mempunyai modal SDM yang produktif dan diharapkan dapat memberikan kontribusi yang optimal dalam penyelenggaraan Pemerintahan Daerah.
\end{abstract}

Kata Kunci: Kinerja, Aparatur Pemerintah, dan pegawai Negeri Sipil

\section{PENDAHULUAN}

Seiring dengan perkembangan zaman, penerapan sistem pemerintahan yang sentralistis dirasa kurang memadai bagi kepentingan daerah, untuk itu perlu dicari suatu sistem yang dapat mengakomodir kepentingan daerah. Dengan dikeluarkannya UndangUndang No. 32 Tahun 2004 tentang Pemerintahan Daerah, penyelenggaraan Otonomi Daerah diwujudkan dengan memberi kewenangan yang luas, nyata dan bertanggung jawab secara proporsional dengan lebih menekankan pada prinsip-prinsip demokrasi, peran serta masyarakat, pemerataan dan keadilan serta dengan memperhatikan potensi dan keanekaragaman daerah. 
Salah satu syarat dalam pelaksanaan Otonomi Daerah adalah, bahwa Pemerintah Daerah harus mampu mempunyai sumber daya aparatur pemerintah yang memiliki kapasitas dan kompetensi yang cukup dalam menyelenggarakan tugas-tugas pemerintahan. Kapasitas sumber daya aparatur ini akan menentukan kemampuan Pemerintah Daerah dalam menjalankan fungsi-fungsinya, seperti melaksanakan fungsi pelayanan masyarakat (public service function) dan melaksanakan pembangunan (development function) serta perlindungan masyarakat (protective function). Terlebih lagi seiring dengan semakin dekatnya era pasar bebas, masing-masing Pemerintah Daerah dituntut untuk dapat memberikan berbagai insentif kebijakan dalam rangka meningkatkan berbagai keunggulan komparatif dan kompetitif yang dimilikinya. Pemerintah Daerah semakin dituntut untuk memiliki kinerja yang lebih baik, sebagai prasyarat komplementer terhadap kinerja institusi tersebut maka kinerja sumber daya aparatur pegawai negeri sipil (PNS) juga semakin dituntut untuk lebih baik kualitasnya.

Kinerja adalah hasil kerja secara kualitas dan kuantitas yang dicapai oleh seorang pegawai dalam melaksanakan tugasnya sesuai dengan tanggung jawab yang diberikan kepadanya (Mangkunegara, 2001: 67). Kinerja dapat diartikan sebagai suatu hasil dan usaha seseorang yang dicapai dengan adanya kemampuan dan perbuatan dalam situasi tertentu. Masih eratnya persepsi masyarakat yang mengatakan bahwa kinerja aparatur Pemerintah Daerah belum sepenuhnya bekerja secara optimal yang ditandai dengan adanya pelayanan birokrat yang cenderung lamban dan bertele-tele sehingga mengakibatkan belum optimalnya kondisi iklim investasi bagi investor serta reformasi birokrasi yang belum berjalan secara optimal dan sebagainya, menjadikan kebutuhan dilakukannya evaluasi kinerja aparatur birokrasi dalam rangka mewujudkan tujuan otonomi memiliki arti yang penting. Berdasrakan hal tersebut maka penelitian ini akan diarahkan pada Evaluasi Kinerja Aparatur Pemerintah Kota Bandar Lampung.

\section{METODE PENELITIAN}

Penelitian ini pada dasarnya adalah bersifat mono variabel. Variabel utamanya adalah Kinerja Aparatur Pemerintah Kota Bandar Lampung. Berdasarkan hal tersebut, maka metode penelitian yang digunakan dalam studi ini adalah analisis deskriptif, yaitu mengadakan pengkajian terhadap fokus kajian studi dan melakukan analisis terhadap gejala-gejala yang meliputi aspek normatif dan empiris. 
Yang menjadi fokus studi dalam penelitian ini antara lain;

1. Kemampuan Teknis, merupakan kemampuan yang dimiliki oleh seorang aparatur pemerintah untuk melaksanakan aktivitas rutin. Kemampuan tersebut dapat di analisis dengan mencermati aspek-aspek; kecakapan teknis kerja, kecepatan kerja, daya tangkap, efisiensi dan efektivitas kerja, penguasaan pekerjaan, dan kualitas kerja.

2. Kemampuan Konseptual, adalah kemampuan untuk melakukan tindakan-tindakan yang membutuhkan tingkat kognitif tertentu. Kemampuan tersebut dapat di analisis dengan mencermati aspek-aspek; kemampuan memimpin, koordinasi, ketergantungan/kemandirian, dan kemampuan komunikasi.

3. Kemampuan Sosial, adalah kemampuan yang dimiliki oleh seorang pegawai untuk berhubungan dengan orang lain. Kemampuan tersebut dapat di analisis dengan mencermati aspek-aspek; kemampuan berhubungan dengan atasan, hubungan dengan sesama teman sekerja, hubungan dengan masyarakat/pelanggan, dan hubungan dengan lingkungan kerja.

\section{HASIL DAN PEMBAHASAN}

\subsection{Kerangka Pengukuran Kinerja}

Pengukuran kinerja merupakan suatu proses mencatat dan mengukur pencapaian pelaksanaan kegiatan dalam arah pencapaian sasaran, tujuan, misi dan visi melalui hasil-hasil yang ditampilkan beberapa produk, jasa ataupun proses pelaksanaan suatu kegiatan. Keberhasilan instansi pemerintah (pemerintah daerah) sering diukur dari sudut pandang kinerjanya masing-masing. Idealnya, pengukuran kinerja yang dipakai oleh instansi pemerintah disusun setelah memperoleh masukan dari lembaga konstituen, sehingga diperoleh suatu konsensus atas apa yang diharapkan oleh stakeholders terhadap organisasi tersebut.

Sampai saat ini, belum ada kebijakan yang mengatur tentang pengukuran kinerja aparatur pemerintah daerah. Adapun aturan yang telah ada yaitu Peraturan Menteri Pendayagunaan Aparatur Negara Nomor Per/09/M.PAN/05/2007 Tentang Pedoman Umum Penetapan Indikator Kinerja Utama Di Lingkungan Instansi Pemerintah, bukan merupakan 
acuan untuk mengukur kinerja aparatur pemerintah (secara individu). Pengukuran kinerja aparatur pemerintah nantinya menjadi salah satu unsur dalam pengukuran kinerja instansi.

\subsubsection{Penetapan Indikator Kinerja}

Indikator kinerja merupakan ukuran kuantitatif dan kualitatif yang menggambarkan tingkat pencapaian suatu sasaran atau tujuan yang telah ditetapkan. Dalam kerangka manajemen aparatur, terdapat evaluasi terhadap kinerjanya yang dilakukan secara berkala oleh atasan tempat dia bekerja atau instansi yang bersangkutan. Penetapan indikator kinerja aparatur pemerintah dilakukan oleh pemerintah daerah dalam rangka penetapan Indikator Kinerja Utama di Lingkungan Instansi Pemerintah Daerah (Pasal 3 Permen PAN Nomor Per/09/M.PAN/05/2007).

\subsubsection{Evaluasi Kinerja}

Evaluasi kinerja merupakan kegiatan lebih lanjut dari kegiatan pengukuran kinerja dan pengembangan indikator kinerja, oleh karena itu dalam melakukan evaluasi kinerja harus berpedoman pada ukuran-ukuran tertentu. Evaluasi kinerja juga merupakan suatu proses umpan balik atas kinerja masa lalu yang berguna untuk meningkatkan produktivitas di masa datang. Sebagai suatu proses yang berkelanjutan, evaluasi kinerja menyediakan informasi mengenai kinerja dalam hubungannya terhadap tujuan dan sasaran.

\section{a. Formasi Aparatur}

Menurut Pasal 1 angka 1 PP 97/2000 tentang Formasi Pegawai Negeri Sipil diatur bahwa formasi adalah jumlah dan susunan pangkat Pegawai Negeri Sipil yang diperlukan dalam suatu Satuan organisasi negara untuk mampu melaksanakan tugas pokok dalam jangka waktu tertentu. Formasi PNS terdiri dari: PNS Pusat dan PNS Provinsi. Pada Pasal 4 PP 97/2000 ditegaskan bahwa formasi masing-masing Satuan organisasi negara disusun berdasarkan analisis kebutuhan dan penyediaan pegawai sesuai dengan jabatan yang tersedia, dengan memperhatikan norma, standar, dan prosedur yang ditetapkan oleh Pemerintah.

Analisis kebutuhan dilakukan berdasarkan:

a. jenis pekerjaan;

b. sifat pekerjaan; 
c. analisis beban kerja dan perkiraan kapasitas seseorang Pegawai Negeri Sipil dalam jangka waktu tertentu;

d. prinsip pelaksanaan pekerjaan; dan

e. peralatan yang tersedia

\section{b. Kinerja Aparatur}

Peraturan yang berkenaan dengan penilaian kinerja aparatur Pemerintah dikaji untuk mendapatkan gambaran yuridis yang jelas tentang pengaturan penilaian kinerja aparatur. Dalam Pasal 12 Undang-Undang Nomor 43 Tahun 1999 tentang Perubahan Atas UndangUndang Nomor 8 Tahun 1974 Tentang Pokok-Pokok Kepegawaian diatur bahwa Manajemen Pegawai Negeri Sipil diarahkan untuk menjamin penyelenggaraan tugas pemerintahan dan pembangunan secara berdaya guna dan berhasil guna, dan untuk mewujudkan penyelenggaraan tugas pemerintah dan pembangunan, diperlukan Pegawai Negeri Sipil yang profesional, bertanggung jawab, jujur, dan adil melalui pembinaan yang dilaksanakan berdasarkan sistem prestasi kerja dan sistem karier yang dititikberatkan pada sistem prestasi kerja.

Berdasrakan aturan tersebut tampak bahwa prinsip yang harus dipegang oleh setiap aparatur pemerintah dalam melaksanakan tugasnya selalu berorientasi pada prestasi kerja. Lebih lanjut, dalam Pasal 13 Undang-Undang Nomor 43 Tahun 1999 diatur bahwa Kebijaksanaan manajemen Pegawai Negeri Sipil mencakup penetapan norma, standar, prosedur, formasi, pengangkatan, pengembangan kualitas sumber daya Pegawai Negeri Sipil, pemindahan, gaji, tunjangan, kesejahteraan, pemberhentian, hak, kewajiban, dan kedudukan hukum.

Penegasan pada pengembangan sumber daya manusia perlu dicermati karena memang filosofi pengaturan undang-undang tersebut dimaksudkan untuk mewujudkan aparatur negara yang bertugas sebagai abdi masyarakat yang akan menyelenggarakan pelayanan secara adil dan merata serta menjaga persatuan dan kesatuan bangsa. Lebih lanjut, diperlukan Pegawai Negeri yang berkemampuan melaksanakan tugas secara profesional dan bertanggung jawab dalam menyelenggarakan tugas pemerintahan dan pembangunan.

Menurut perumusan kebijakan kepegawaian, Pasal 13 Ayat (3) UU No 43 Tahun 1999 tentang Perubahan terhadap UU No.8 Tahun 1974 tentang Pokok Pokok Kepegawaian 
Negara menetapkan adanya komisi independen tersebut yaitu Komisi kepegawaian Negara yang terdiri atas 5 anggota yang mewakili stakeholder penting yang belum dibentuk oleh Pemerintah. Bentuk lembaga independen seperti ini makin banyak digunakan di berbagai negara karena dipandang sebagai bentuk kelembagaan yang lebih cocok untuk mewadahi proses perumusan kebijakan yang lebih demokratis.

\subsection{Deskripsi Kewenangan Kota Bandar Lampung}

Kewenangan dan Tata Kerja Organisasi yang menjadi landasan kerja bagi Pemerintah Kota Bandar Lampung diatur dalam Perda, yaitu:

1) Perda Kota Bandar Lampung Nomor 4 Tahun 2009 tentang Perubahan atas Peraturan Daerah Nomor 2 Tahun 2008 tentang Organisasi dan Tata Kerja secretariat Daerah Kota, Sekretariat Daerah Kota, Sekretariat Dewan Perwakilan Perwakilan Rakyat Daerah Kota dan Staf Ahli Walikota Bandar Lampung.

2) Berdasarkan kajian terhadap Perda Kota Bandar Lampung Nomor 4 Tahun 2009 tentang Perubahan atas Peraturan Daerah Nomor 2 Tahun 2008 tentang Organisasi dan Tata Kerja secretariat Daerah Kota, Sekretariat Daerah Kota, Sekretariat Dewan Perwakilan Perwakilan Rakyat Daerah Kota dan Staf Ahli Walikota Bandar Lampung, yaitu:

a. Sekretaris Daerah

b. Asisten Bidang Pemerintahan, yang membawahi:

1. Bagian Pemerintahan membawahi

1) Sub Bagian Tata Pemerintahan Umum;

2) Sub Bagian Pemerintahan Kelurahan; dan

3) Sub Bagian Perkotaan.

2. Bagian Hukum, membawahi:

1) Sub Bagian Perundang-undangan;

2) Sub Bagian Penyuluhan dan Bantuan Hukum;

3) Sub Bagian Informasi dan Dokumen Hukum.

3. bagian Organisasi, membawahi:

1) Sub Bagian Kelembagaan;

2) Sub Bagian tata Laksana;

3) Sub Bagian Analisa Jabatan dan Kepegawaian Sekretariat. 
c. Asisten Bidang Perekonomian dan Pembangunan, yang membawahi:

1. Bagian Perekonomian, membawahi:

1) Sub Bagian Ekonomi Kerakyatan;

2) Sub Bagian Jasa Produksi;

3) Sub Bagian Sarana Perekonomian.

2. Bagian Administrasi Pembangunan, membawahi:

1) Sub Bagian penyusunan Program;

2) Sub Bagian Pengendalian Program;

3) Sub Bagian Pelaporan.

3. bagian Perlengkapan Sekretariat, membawahi:

1) Sub Bagian Analisa Kebutuhan;

2) Sub Bagian Pengadaan Barang;

3) Sub Bagian Penyimpanan dan Distribusi

d. Asisten Bidang Administrasi, yang membawahi:

1. Bagian Hubungan Masyarakat, membawahi:

1) Sub Bagian Pengumpulan data dan Penyaringan informasi;

2) Sub Bagian Publikasi dan Dokumentasi

3) Sub Bagian Pengelola Data dan Hubungan antar Lembaga

2. Bagian Umum, membawahi:

1) Sub Bagian Tata Usaha Sekretariat;

2) Sub Bagian Keuangan Sekretariat;

3) Sub Bagian Rumah Tangga.

3. Bagian Protokol, membawahi:

1) Sub Bagian tata Usaha dan Perjalanan Dinas Pipinan;

2) Sub Bagian Tamu Pemerintah daerah, Rapat-rapat Dinas dan Upacara;

3) Sub Bagian sandi dan Telekomunikasi.

e. Kelompok Jabatan Fungsional

2. Perda Kota Bandar Lampung Nomor 5 Tahun 2009 tentang Perubahan Atas Perda Nomor 3 Tahun 2008 tentang Organisasi dan Tata Kerja Dinas Daerah Kota Bandar Lampung;

Berdasarkan Perda tersebut, maka dibentuklah Dinas daerah yang terdiri dari: 

a. Dinas Pendidikan;
b. Dinas Kesehatan;
c. Dinas Pekerjaan Umum;
d. Dinas Perhubungan;
e. Dinas kependudukan dan Catatan Sipil;
f. Dinas Tenaga Kerja;
g. Dinas Koperasi, Usaha Kecil Menengah, Perindustrian dan Perdagangan
h. Dinas Pemuda dan Olahraga;
i. Dinas Kebudayaan dan Pariwisata;
j. Dinas Kelautan dan Perikanan;
k. Dinas Kebersihan dan Pertamanan;
1. Dinas Sosial;
m. Dinas Pertanian, Peternakan dan Kehutanan;
n. Dinas Tata Kota;
o. Dinas Pendapatan, Pengelolaan Keuangan dan Aset;
p. Dinas Pengelolaan Pasar;

\subsection{Kinerja Aparatur Pemerintah Kota Bandar Lampung}

Guna mengetahui kinerja Aparatur Pemerintah Kota Bandar Lampung digunakan kriteria seperti yang dikemukakan Cascio (1992), dan juga ketentuan tentang disiplin Pegawai Negeri Sipil. Cascio mengemukakan tiga dimensi utama dalam mengetahui kinerja pegawai, yaitu kemampuan teknis, kemampuan konseptual, dan kemampuan sosial. Penilaian terhadap kinerja aparatur pemerintah dalam penelitian ini dilakukan sendiri oleh Aparatur Pemerintah Kota Bandar Lampung yang terpilih menjadi responden. Jumlah kuesioner 100 buah, yang kembali dengan isian lengkap sejumlah 100 buah kuesioner, sehingga jumlah respondennya adalah 100 orang.

Jenis kelamin responden dalam penelitian ini laki-laki 40 orang $(37,30 \%)$ dan perempuan 60 orang (62,70\%). Posisi seperti ini dapat dikatakan cukup berimbang jika dibandingkan dengan jumlah aparatur pemerintah Propinsi Lampung yang berjenis kelamin perempuan, yaitu sebesar $62,70 \%$. Dengan demikian responden perempuan telah terwakili dengan baik. Begitu juga dengan responden yang laki-laki. 
Pendidikan responden didominasi lulusan sarjana (S1) berjumlah 30 orang (30\%). Pasca Sarjana (S2) berjumlah 10 orang (10\%), Sekolah Lanjutan Tingkat Atas berjumlah 35 orang (35\%) dan disusul pendidikan Diploma IV sebanyak 25 orang (25\%).

Usia responden sebagian besar umur 35-55 tahun sebanyak 60 orang (60\%), umur 2134 tahun sebanyak 30 orang (20\%), umur di atas 56 tahun sebanyak 10 orang (10\%). Dari segi usia responden didominasi oleh sumberdaya manusia pada masa produktif, yaitu usia 3050 tahun. Dengan kondisi responden yang demikian ini sangat tepatlah untuk dapat mengetahui kinerja aparatur pemerintah Kota Bandar Lampung yang sebenarnya.

\section{A. Kemampuan Teknis}

Kemampuan teknis aparatur pemerintah dinilai dari enam aspek. Kemampuan teknis di dalamnya mengandung aspek disiplin aparatur. Enam aspek tersebut mencakup:

1) Kemampuan dan kecakapan teknis dalam melaksanakan tugas pekerjaan (kemampuan kerja).

2) Kesanggupan dan kecepatan dalam mencapai hasil kerja dan mutu kerja sesuai ketentuan yang berlaku (kecepatan kerja).

3) Kesanggupan menghayati serta melaksanakan instruksi, pedoman dan metode kerja yang telah ditentukan (daya tangkap).

4) Kemampuan bekerja secara efektif dan efisien.

5) Penguasaan/pengetahuan untuk bekerja secara efektif dan efisien (penguasaan pekerjaan).

6) Mutu pekerjaan yang diselesaikan dalam suatu periode tertentu (kualitas kerja).

\subsubsection{Kemampuan dan kecakapan teknis dalam melaksanakan tugas pekerjaan (kemampuan kerja)}

Hasil penyebaran kuesioner diperoleh data bahwa sebagian besar aparatur pemerintah Kota Bandar Lampung (50\%) dalam hal kemampuan kerjanya berada pada posisi cukup. Artinya mereka masih membutuhkan bimbingan dan pengarahan ataupun petunjuk untuk dapat menyelesaikan pekerjaannya. Pada posisi baik sekali artinya mereka dapat menyelesaikan pekerjaan dengan baik sekali tanpa ada kesalahan, sebanyak 26\%. Posisi cukup menunjukkan pada angka 16\% juga, artinya aparatur pemerintah dalam penyelesaian 
pekerjaan cukup baik meski kadang kala masih ada kesalahan. Hanya $1 \%$ aparatur pemerintah yang dapat menyelesaikan pekerjaan sangat baik tanpa cacat sedikit pun. Lebih jelasnya dapat dilihat tabel berikut:

Tabel 1. Kemampuan Kerja

Aparatur Pemerintah Kota Bandar Lampung

\begin{tabular}{|l|l|l|r|r|}
\hline No & \multicolumn{1}{|c|}{ Kemampuan Kerja } & \multicolumn{1}{|c|}{ Sebutan } & \multicolumn{1}{c|}{ F } & \multicolumn{1}{c|}{$\%$} \\
\hline 1. & Sangat Istimewa tanpa cacat & Istimewa & 1 & 1 \\
2. & Baik Sekali tidak pernah ada kesalahan & Baik sekali & 26 & 26 \\
3. & Menyelesaikan tugas dengan hasil cukup baik & Baik & 50 & 50 \\
4. & Cukup namun masih perlu petunjuk & Cukup & 16 & 16 \\
5. & Masih perlu bimbingan dan pengawasan & Kurang & 7 & 7 \\
\hline \multicolumn{2}{|c|}{ Total } & $\mathbf{1 0 0}$ & $\mathbf{1 0 0}$ \\
\hline
\end{tabular}

\subsubsection{Kesanggupan dan kecepatan dalam mencapai hasil kerja dan mutu kerja sesuai ketentuan yang berlaku (kecepatan kerja)}

Kemampuan aparatur pemerintah dalam hal kecepatan menyelesaikan pekerjaan pada umumnya menduduki posisi baik sekali, yaitu 46\%. Artinya mereka dapat menyelesaikan pekerjaan begitu tepat waktu dan jarang melewati batas waktu yang ditentukan. Posisi kedua yaitu 38\% menyatakan dapat menyelesaikan pekerjaan tepat. Terdapat $13 \%$ aparatur pemerintah yang dapat menyelesaikan pekerjaan tepat waktu meskipun terkadang masih terlambat juga. Sedangkan responden yang belum dapat mengukur bagaimana kemampuannya dalam menyelesaikan pekerjaan sebesar $2 \%$.

Bila kemampuan aparatur pemerintah ini dikaitkan dengan prestasi kerja, tentunya masih harus ditingkatkan lagi. Dalam posisi ini baru dalam tahap bisa mencapai target yaitu tepat waktu, tapi belum dapat melampaui target. Pada dasarnya dalam administrasi pemerintahan meskipun sudah mencapai target sebenarnya masih bisa ditingkatkan lagi. Karena bukan rahasia umum lagi bahwa dalam menetapkan suatu target pekerjaan, umumnya ditetapkan secara minimalis, tidak berani menetapkan maksimum. Sebab ada suatu ketakutan jika suatu instansi sudah menetapkan target kemudian tidak tercapai, instansi ataupun 
pejabatnya langsung dikatakan tidak mampu bekerja tanpa melihat sebab musababnya. Hal inilah yang kemudian melatarbelakangi dalam menetapkan target menggunakan rumus minimalis.

\subsubsection{Kemampuan bekerja secara efektif dan efisien}

Kemampuan aparatur pemerintah Kota Bandar Lampung dalam hal effektivitas dan efisiensi kerja adalah cukup baik dan hasilnya cukup baik (masuk dalam kategori baik), hal ini menduduki posisi tertinggi yaitu 67\%. Effektivitas dan efisiensi kerja tinggi dan hasilnya baik menududuki posisi kedua yaitu 27\%. Dalam kondisi ini berarti aparatur pemerintah masih harus didorong untuk dapat meningkatkan effektivitas dan efisiensi kerjanya.

Kemampuan semacam ini sangat diperlukan pada saat suatu instansi bertugas memberikan pelayanan langsung kepada masyarakat ataupun dalam hal melaksanakan tugas rutinnya. Dengn kondidi ini masyarakat mempunyai harapan yang besar bahwa mereka dapat terlayani dengan baik dan cepat. Sehingga citra pelayanan pemerintah daerah yang selama ini diklaim masyarakat lamban dan berbelit-belit dapat ditepisnya.

\subsubsection{Penguasaan/pengetahuan untuk bekerja secara efektif dan efisien (penguasaan pekerjaan)}

Kemampuan aparatur pemerintah Kota Bandar Lampung dalam hal penguasaan pekerjaan adalah baik tanpa hambatan berarti (masuk dalam kategori baik sekali) sebesar 47\%., Kategori baik dalam pengertian penguasaan pekerjaannya cukup baik dan mampu melaksanakan tugas pada tingkat yang sedang, sebesar 49\%. Namun demikian pantas mendapat pujian juga karena terdapat 12,5\% aparatur pemerintah Kota Bandar Lampung yang dalam hal penguasaan pekerjaan baik sekali tanpa hambatan sama sekali (istimewa) dan tidak ada satupun aparatur pemerintah yang penguasaan pekerjaannya kurang. Meskipun demikian perlu adanya upaya pemerintah daerah dalam pengembangan SDM agar dapat meningkatkan kemampuan penguasaan pekerjaannya. 


\subsubsection{Mutu pekerjaan yang diselesaikan dalam suatu periode tertentu}

\section{(Kualitas Kerja)}

Tabel 2. menggambarkan bahwa kemampuan aparatur pemerintah Kota Bandar Lampung dalam hal kualitas kerja adalah cukup memenuhi apa yang diperlukan (masuk dalam kategori baik) sebesar 65\%, dan menduduki posisi tertinggi. Kategori istimewa menduduki posisi kedua yaitu 6\%, dalam pengertian kualitas pekerjaan sangat baik. Posisi ketiga adalah baik sekali dalam pengertian hasil pekerjaan baik melebihi yang diperlukan, yaitu sebesar 23\%. Berdasarkan kondisi demikian pemerintah daerah harus berupaya untuk meningkatkan kinerja melalui pelatihan-pelatihan keterampilan agar kualitas kerja dapat optimal.

Hal itu sejalan dengan misi Pemerintah Kota Bandar Lampung dalam rangka pembangunan untuk mewujudkan sumberdaya manusia yang bertaqwa, sejahtera, berkualitas, berakhlaq mulia, profesional, unggul dan berdaya saing.

Dari paparan data di atas kinerja aparatur Pemerintah Kota Bandar Lampung dalam hal kemampuan teknisnya baik sekali mencapai 40\%, kemampuannya baik mencapai 49\%, sementara yang mempunyai kemampuan istimewa sebesar 3,3\%. Lebih jelasnya dapat diperhatikan tabel 2. berikut ini.

Tabel 2. Kemampuan Teknis

Aparatur Pemerintah Kota Bandar Lampung

\begin{tabular}{|c|c|c|c|c|c|c|c|c|}
\hline No & $\begin{array}{c}\text { Kemampuan } \\
\text { teknis }\end{array}$ & Istimewa & $\begin{array}{c}\text { Baik } \\
\text { sekali }\end{array}$ & Baik & Cukup & Kurang & $\begin{array}{c}\text { Tanpa } \\
\text { keterangan }\end{array}$ & Total \\
\hline 1 & $\begin{array}{c}\text { Kemampuan } \\
\text { Kerja }\end{array}$ & 1 & 26 & 50 & 16 & 7 & 0 & 100 \\
\hline 2 & $\begin{array}{c}\text { Kecepatan } \\
\text { Kerja }\end{array}$ & 1 & 46 & 38 & 13 & 0 & 2 & 100 \\
\hline 3 & $\begin{array}{c}\text { Daya } \\
\text { Tangkap }\end{array}$ & 3 & 71 & 24 & 1 & 0 & 1 & 100 \\
\hline 4 & $\begin{array}{c}\text { Efisiensi \& } \\
\text { efektivitas } \\
\text { kerja }\end{array}$ & 5 & 27 & 67 & 1 & 0 & 0 & 100 \\
\hline 5 & Penguasaan & 4 & 47 & 49 & 0 & 0 & 0 & 100 \\
\hline
\end{tabular}




\begin{tabular}{|c|c|c|c|c|c|c|c|c|}
\hline 6 & $\begin{array}{c}\text { Pekerjaan } \\
\text { Kualitas } \\
\text { Kerja }\end{array}$ & 6 & 23 & 65 & 4 & 1 & 1 & 100 \\
\hline Total & $\begin{array}{c}20 \\
(3,3 \%)\end{array}$ & $\begin{array}{c}240 \\
(40 \%)\end{array}$ & $\begin{array}{c}294 \\
(49 \%)\end{array}$ & $\begin{array}{c}35 \\
(5,8 \%)\end{array}$ & $\begin{array}{c}8 \\
(1,3 \%)\end{array}$ & $\begin{array}{c}3 \\
(0,5 \%)\end{array}$ & $\begin{array}{c}600 \\
(100 \%)\end{array}$ \\
\hline
\end{tabular}

Berdasarkan data yang ada, kemampuan teknis Aparatur Pemerintah Kota Bandar Lampung masih perlu ditingkatkan berdasarkan skala prioritas mulai dari kemampuan kerja, efisiensi dan efektivitas kerja, penguasaan pekerjaan, kualitas kerja dan daya tangkapnya. Oleh karenanya dalam hal penempatan personel dalam suatu jabatan harus diperhatikan mulai dari pengalaman kerja, keterampilan, pendidikan dan pangkat/golongan.

\subsubsection{Kemampuan Konseptual}

Kemampuan konseptual aparatur pemerintah dinilai dari empat aspek. Empat aspek tersebut mencakup: kemampuan memimpin (diri sendiri dan orang lain), kemampuan koordinasi, kemandirian, kemampuan berkomunikasi untuk menyampaikan/ menerima gagasan. Untuk mengetahui kemampuan aparatur dari aspek ini dapat diperhatikan uraian berikut.

\section{a. Kemampuan Memimpin (diri sendiri ataupun orang lain)}

Dari jawaban 100 responden terdapat 64\% atau sejumlah 64 orang responden menyatakan bahwa kemampuan memimpinnya berada pada kategori baik, dalam pengertian punya kemampuan dan telah konsisten dalam menjalankan tugas dan fungsinya sebagai pemimpin baik terhadap diri sendiri ataupun terhadap orang lain. Aparatur pemerintah yang lainnya yaitu $11 \%$ atau 11 orang responden mempunyai kemampuan memimpin namun belum konsisten, yaitu masuk dalam kategori cukup. Dari data inilah perlu adanya upaya pemerintah daerah untuk pengembangan aparaturnya agar dapat menjadi pemimpin yang baik. Lebih jelasnya dapat diperhatikan tabel 3. berikut:

Tabel 3. Kemampuan Memimpin 


\begin{tabular}{|l|l|l|r|r|}
\hline No & \multicolumn{1}{|c|}{ Kemampuan Memimpin } & \multicolumn{1}{|c|}{ Sebutan } & \multicolumn{1}{c|}{ F } & \multicolumn{1}{c|}{ \% } \\
\hline 1 & Sangat menonjol dan sangat berbakat & Istimewa & 2 & 2 \\
3 & Menonjol dan berbakat & Baik sekali & 19 & 19 \\
4 & Berkemampuan dan sudah konsisten & Baik & 64 & 64 \\
& $\begin{array}{l}\text { Menunjukkan kemampuan tapi belum } \\
\text { konsisten }\end{array}$ & Cukup & 11 & 11 \\
5 & $\begin{array}{l}\text { Kurang ada kemampuan dan masih perlu } \\
\text { bimbingan ketat }\end{array}$ & Kurang & 2 & 2 \\
\hline \multicolumn{2}{|c|}{ Total } & $\mathbf{1 0 0}$ & $\mathbf{1 0 0 \%}$ \\
\hline
\end{tabular}

\section{b. Kemampuan Koordinasi}

Tabel 9. memberikan gambaran bahwa kemampuan aparatur pemerintah Kota Bandar Lampung dalam hal kemampuannya untuk berkoordinasi menunjukkan $45 \%$ baik. Artinya mereka mampu berkoordinasi dan selalu berusaha untuk lebih maju. Kemudian 10\% mempunyai kemampuan cukup, yaitu cukup mampu berkoordinasi dan cadangan kemampuan untuk berusaha. Di sisi lain ada juga yang mempunyai kemampuan baik sekali $41 \%$ dan istimewa $2 \%$.

Dari data di atas kemampuan berkoordinasi pada umumnya dapat dikatakan baik, miskipun harus ditingkatkan lagi agar berkemampuan tinggi dengan penguasaan sangat baik atau setidak-tidaknya mereka mampu dan menguasai dengan baik.

\section{c. Kemampuan ketidaktergantungan/kemandirian}

Kemampuan kemandirian aparatur pemerintah Kota Bandar Lampung lebih dari lima puluh persen, yaitu 54\% adalah baik sekali. Mereka mempunyai kemandirian baik sekali, yaitu pengawasan dan bimbingan hanya dalam hal khusus/ tugas-tugas khusus. Kemudian 
$25 \%$ adalah cukup dimana dalam melaksanakan tugas masih memerlukan bimbingan yang layak. Artinya mereka belum bisa mandiri atau masih ketergantungan dengan orang lain.

Berdasarkan data yang terkumpul ini, dirasa masih perlu untuk memberikan motivasi dan kepercayaan diri kepada aparatur pemerintah untuk dapat melaksanakan tugas secara mandiri. Tentunya dengan pelatihan-pelatihan.

\section{d. Kemampuan berkomunikasi untuk menyampaikan/ menerima gagasan}

Berdasarkan hasil penelitian memberikan suatu gambaran bahwa lima puluh persen lebih (69\%) aparatur pemerintah Kota Bandar Lampung berkemampuan untuk menyampaikan dan atau menerima gagasan dengan baik sekali. Kemudian 5\% berkemampuan istimewa, dan masing-masing $7 \%$ berkemampuan cukup dan $17 \%$ berkemampuan baik, serta tidak ada yang kurang dapat berkomunikasi.

Dengan data yang demikian ini dapat dikatakan bahwa aparatur pemerintah Kota Bandar Lampung pada umumnya dalam hal kemampuan berkomunikasi adalah baik sekali. Berarti sudah terjalin komunikasi dua arah yaitu mampu menyampaikan ide dengan baik serta mampu menyerap/menerima gagasan dari orang lain dengan baik pula. Sebab akan fatal akibatnya jika orang hanya mampu menyampaikan ide tanpa mampu menerima gagasan dari orang lain. Konsekuensinya menjadi orang yang otoriter. Begitu pula sebaliknya orang hanya mampu menerima saja tanpa mampu menyampaikan ide/gagasan dengan baik, ini akan membuat orang stres ditambah lagi atasan yang tidak mengerti kondisi bawahannya.

Meskipun sudah dikatakan baik sekali bukan berarti hal ini sudah cukup, tetapi masih tetap harus ditingkatkan supaya mampu melakukan komunikasi dalam situasi/kondisi apapun. Dari paparan data di atas secara umum kinerja aparatur Pemerintah Kota Bandar Lampung dalam tataran kemampuan konseptualnya sudah baik, yaitu 35,5\% dikategorikan baik, 45,75\% dikategorikan baik sekali dan 2,75\% dikategorikan istimewa, sehingga yang masuk kategori cukup dan kurang tidak lebih dari 20\%. Lebih jelasnya dapat diperhatikan tabel berikut ini. 
Tabel 4. Kemampuan Konseptual Aparatur

Pemerintah Propinsi Lampung

\begin{tabular}{|l|l|c|c|c|c|c|c|c|}
\hline No & $\begin{array}{l}\text { Kemampuan } \\
\text { konseptual }\end{array}$ & Istimewa & $\begin{array}{c}\text { Baik } \\
\text { Sekali }\end{array}$ & Baik & Cukup & Kurang & $\begin{array}{c}\text { Tidak } \\
\text { ada } \\
\text { jwb }\end{array}$ & Total \\
\hline 1 & $\begin{array}{l}\text { Kemampuan } \\
\text { memimpin }\end{array}$ & 2 & 19 & 64 & 11 & 2 & 2 & 104 \\
\hline 2 & $\begin{array}{l}\text { Kemampuan } \\
\text { koordinasi }\end{array}$ & 2 & 41 & 45 & 10 & 1 & 1 & 104 \\
\hline 3 & $\begin{array}{l}\text { Kemandirian } \\
4\end{array}$ & 2 & 54 & 16 & 25 & 2 & 2 & 104 \\
\hline & $\begin{array}{l}\text { Berkomunika } \\
\text { si }\end{array}$ & 5 & 69 & 17 & 7 & 0 & 0 & 104 \\
\hline & Jumlah & $(2,75 \%)$ & $(45,75$ & $(35,5$ & $(13,25$ & $(1,25 \%)$ & $(1,5 \%)$ & $(100$ \\
\hline
\end{tabular}

Meskipun kemampuan konseptual aparatur pemerintah Kota Bandar Lampung sudah termasuk dalam kategori baik atau pun baik sekali, namun tetap perlu adanya upaya peningkatan kemampuan konseptual, melalui berbagai pelatihan/kursus-kursus. Pemerintah daerah dalam melakukan pengembangan sumber daya manusia harus memperhatikan skala prioritas, misalnya lebih dikedepankan untuk memberikan pelatihan tentang kemampuan memimpin dan koordinasi. Ternyata dalam praktek tidak mudah untuk melaksanakan suatu koordinasi, dibandingkan untuk berkomunikasi.

\section{e. Kemampuan Sosial}

\section{Kemampuan untuk membina hubungan dengan atasan dalam menyelesaikan pekerjaan}

Hasil penelitian memberikan suatu gambaran bahwa lima puluh persen lebih yaitu 57\% aparatur pemerintah Kota Bandar Lampung berkemampuan untuk membina hubungan dengan atasannya baik sekali. Artinya mereka mampu menerima tugas dari atasan dan 
melaksanakannya dengan baik. Kemudian $16 \%$ berkemampuan istimewa, dan masing-masing $20 \%$ berkemampuan cukup dan $20 \%$ berkemampuan baik, serta tidak satupun aparatur Pemerintah Kota Bandar Lampung yang tidak bisa menerima tugas dan melaksanakannya. Dalam hal ini, tidak aparatur pemerintah yang berani membantah perintah atasannya.

Dengan demikian dapat dikatakan bahwa kemampuan aparatur pemerintah untuk membina hubungan dengan atasan sudah baik bahkan baik sekali.

\section{Kemampuan untuk membina hubungan kerja sama dengan teman sekerja dalam menyelesaikan pekerjaan}

Kemampuan membina hubungan kerja dengan teman kerja aparatur pemerintah Kota Bandar Lampung lima puluh persen lebih, yaitu 59\% adalah baik sekali. Mereka mampu membina hubungan kerja dengan baik. Kemudian 18\% mempunyai kemampuan baik, yaitu selalu berusaha untuk bersikap baik.

Di sinilah letak positif aparatur pemerintah Kota Bandar Lampung yaitu dengan kesadaran sendiri bahwa mereka tidak bisa hidup sendiri. Mereka membutuhkan orang lain. Oleh karenanya dalam hal ini tidak ada satu pun aparatur pemerintah yang tidak mau membina hubungan dengan teman kerjanya. Kondisi ini terus perlu diupayakan dan dipertahankan guna menciptakan lingkungan kerja yang nyaman.

\section{Kemampuan membina hubungan dengan pengguna/} pelanggan/masyarakat yang berkepentingan dengan lingkup kerja

Hasil penelitian memberikan suatu gambaran bahwa 26\% aparatur pemerintah Kota Bandar Lampung berkemampuan untuk membina hubungan dengan pelanggan/masyarakat secara istimewa. Artinya mereka mampu bersikap ramah, sopan dan simpatik dengan pelanggan/masyarakat. Meskipun hal ini belum dapat menjadi ukuran atau menjadi rujukan tentang indeks kepuasan masyarakat. Karena angka ini diperoleh bukan dari hasil penilaian masyarakat, namun hasil penilaian diri sendiri aparatur pemerintah.

Semoga dengan kondisi seperti ini menjadi cambuk bagi aparatur pemerintah untuk dapat memberikan pelayanan yang optimal kepada masyarakat. Kemudian $65 \%$ mampu 
membina hubungan yang baik sekali, dan masing-masing $4 \%$ berkemampuan baik dan $4 \%$ berkemampuan cukup, serta tidak satupun aparatur Pemerintah Kota Bandar Lampung yang bersikap kurang baik terhadap pelanggan/masyarakat dalam kondisi apapun.

\section{Kemampuan membina hubungan dengan lingkungan kerja}

Data yang berhasil dikumpulkan memberikan gambaran bahwa kemampuan aparatur pemerintah Kota Bandar Lampung dalam membina hubungan dengan lingkungan tempat kerja yaitu 52\% adalah baik sekali. Mereka mampu membina hubungan dengan lingkungan tempat kerja. Kemudian 4\% mempunyai kemampuan istimewa, yaitu hubungan mereka sangat baik dan terbiasa tanpa hambatan sama sekali. Kondisi seperti ini perlu ditingkatkan dan dipertahankan guna menciptakan suasana kerja yang nyaman.

Dari paparan data di atas dapat dikatakan bahwa kinerja aparatur Pemerintah Kota Bandar Lampung pada tataran kemampuan sosial dalam kondisi baik sekali, yaitu mencapai $59 \%$, disusul kondisi baik 20\%, istimewa 15,5\%, dan cukup 4,5\%.

Data ini menggambarkan bahwa perlu adanya peningkatan kemampuan sosial, mengingat masih terdapat kemampuan sosial sebatas baik dan cukup tidak lebih dari $30 \%$.

Tabel 5. Kemampuan Sosial

Aparatur Pemerintah Kota Bandar Lampung

\begin{tabular}{|c|l|c|c|c|c|c|c|c|}
\hline No & \multicolumn{1}{|c|}{$\begin{array}{c}\text { Kemampuan } \\
\text { Sosial }\end{array}$} & $\begin{array}{c}\text { Istimew } \\
\text { a }\end{array}$ & $\begin{array}{c}\text { Baik } \\
\text { sekali }\end{array}$ & Baik & Cukup & Kurang & $\begin{array}{c}\text { Tidak } \\
\text { ada } \\
\text { jwb }\end{array}$ & Total \\
\hline 1 & $\begin{array}{l}\text { Hubungan dengan } \\
\text { atasan }\end{array}$ & 16 & 57 & 20 & 6 & 0 & 1 & 100 \\
\hline 2 & $\begin{array}{l}\text { Hubungan dengan } \\
\text { sesama teman } \\
\text { kerja }\end{array}$ & 16 & 62 & 18 & 4 & 0 & 0 & 100 \\
\hline 3 & $\begin{array}{l}\text { Hubungan dengan } \\
\text { pelanggan/ } \\
\text { masyarakat } \\
\text { pengguna }\end{array}$ & 26 & 65 & 4 & 4 & 0 & 1 & 100 \\
\hline
\end{tabular}




\begin{tabular}{|c|c|c|c|c|c|c|c|c|}
\hline 4 & $\begin{array}{c}\text { Hubungan dengan } \\
\text { lingkungan kerja }\end{array}$ & 4 & 52 & 38 & 4 & 0 & 2 & 100 \\
\hline Jumlah & $\begin{array}{c}62 \\
(15,5 \%)\end{array}$ & $\begin{array}{c}236 \\
(59 \%)\end{array}$ & $\begin{array}{c}80 \\
(20 \%)\end{array}$ & $\begin{array}{c}18 \\
(12,5 \%)\end{array}$ & $\begin{array}{c}(0 \%) \\
(1 \%)\end{array}$ & $\begin{array}{c}(100 \\
\%)\end{array}$ \\
\hline
\end{tabular}

Dalam peningkatan kemampuan aparatur pemerintah dalam hal kemampuan sosial perlu adanya skala prioritas, dan semestinya kondisi yang telah baik ini benar-benar dapat dirasakan oleh masyarakat sekitar, pelanggan maupun oleh aparatur pemerintah Kota Bandar Lampung itu sendiri. Prioritas untuk dikembangkan adalah membina hubungan baik dengan lingkungan kerja, membina hubungan dengan teman sekerja, membina hubungan baik dengan pelanggan dan dengan atasan. Kemampuan sosial yang baik akan menciptakan suasana kerja yang nyaman. Suasana kerja yang nyaman dapat menumbuhkan prestasi kerja yang optimal.

\section{Reward dan Punishment}

Peningkatan kinerja aparatur pemerintah Kota Bandar Lampung harus mampu untuk memberikan kesejahteraan aparaturnya, memberikan reward bagi yang berprestasi, menegakkan aturan yang ada, misalnya dalam promosi jabatan. Jangan sampai terjadi ketidakpastian dan ketidakadilan dalam menerapkan aturan yang ada.

Setelah diketahui kemampuan aparatur pemerintah Kota Bandar lampung dari masing-masing aspek, dibawah ini dapat diketahui kinerja aparatur pemerintah Kota Bandar Lampung secara menyeluruh mulai dari kemampuan teknis, kemampuan konseptual, dan kemampuan social, berada pada posisi baik sekali $36,25 \%$, baik $34,83 \%$, cukup $7,88 \%$ dan istimewa pada posisi $7,18 \%$. Sementara itu berada pada kondisi kurang hanya sebesar $1,48 \%$.

Table 6. Kinerja aparatur Pemerintah kota Bandar Lampung

\begin{tabular}{|c|l|c|c|c|c|c|c|}
\hline No & \multicolumn{1}{|c|}{ Aspek } & Istimewa & $\begin{array}{c}\text { Baik } \\
\text { sekali }\end{array}$ & Baik & cukup & kurang & $\begin{array}{c}\text { Tidak } \\
\text { ada jwb }\end{array}$ \\
\hline 1 & $\begin{array}{l}\text { Kemampuan } \\
\text { teknis }\end{array}$ & 3,3 & 40 & 49 & 5,9 & 1,3 & 0,5 \\
2 & Kemampuan & 2,75 & 45,75 & 35,5 & 13,25 & 1,25 & 1,5 \\
\hline
\end{tabular}




\begin{tabular}{|c|l|c|c|c|c|c|c|}
\hline 3 & $\begin{array}{l}\text { konseptual } \\
\text { Kemampuan } \\
\text { sosial }\end{array}$ & 15,5 & 59 & 20 & 4,5 & 0 & 1 \\
\hline & Jumlah (\%) & 21,55 & 108,75 & 104,5 & 23,65 & 2,55 & 3 \\
& Rerata (\%) & 7,18 & 36,25 & 34,83 & 7,88 & 0,85 & 1 \\
\hline
\end{tabular}

Oleh karenanya kedepan dalam rangka peningkatan kinerja aparatur Pemerintah Kota Bandar Lampung dapat dilakukan dengan skala prioritas secara berurutan mulai dari peningkatan kemampuan teknis, kemampuan konseptual dan kemampuan sosial.

\section{PENUTUP}

\subsection{Kesimpulan}

a. Pemerintah Kota Bandar Lampung mempunyai modal SDM yang produktif dan diharapkan dapat memberikan kontribusi yang optimal dalam Penyelenggaraan Pemerintahan Daerah.

b. Kinerja aparatur Pemerintah Kota Bandar Lampung sekarang ini berada pada posisi: istimewa $(7,18 \%)$, baik sekali $(36,25 \%)$, baik $(34,83 \%)$ cukup $(7,88 \%)$ dan kurang $(0,85 \%)$.

c. Terdapat enam faktor yang mempengaruhi kinerja aparatur pemerintah Kota Bandar Lampung:

1) keteladanan;

2) pembagian beban kerja;

3) objektivitas dalam pembinaan aparatur pemerintah;

4) penegakan hukum;

5) penerapan reward/punisment, dan

6) keterampilan tertentu (komputer dan bahasa Inggris). 


\subsection{Rekomendasi}

Merujuk hasil penelitian di lapangan, terdapat beberapa hal yang dapat dilakukan Pemerintah Kota Bandar Lampung untuk meningkatkan kinerja aparatur pemerintah, antara lain:

a. Melakukan penilaian oleh atasan langsung secara obyektif, transparan dan akuntabel terhadap kinerja aparatur pemerintah secara periodik setiap tahun, sebagai bahan rujukan dalam melakukan penilaian terhadap aparatur pemerintah Kota Bandar Lampung.

b. Sumberdaya aparatur pemerintah yang telah ada perlu lebih ditingkatkan melalui pelatihan-pelatihan, bimbingan teknis, serta keteladanan perilaku dan sikap dari atasan.

c. Pembinaan aparatur pemerintah daerah diprioritaskan menggunakan merit system.

d. Memberikan insentif (reward) bagi yang berprestasi atau yang kinerjanya baik dan memberikan hukuman bagi yang kinerjanya buruk.

e. Pola rekrutmen aparatur lebih didasarkan pada analisis jabatan sesuai dengan tingkat kebutuhannya dengan prioritas yang lebih diarahkan pada tenaga teknis (fungsional), bagi terwujudnya struktur kepegawaian yang ideal sesuai dengan tuntutan dan perkembangan organisasi serta pelayanan publik. 


\section{Daftar Pustaka}

Cassio. F.W, 1992. Managing Human Resources: Productivity, Quality of Work Life, Profits $3^{\text {rd }}$.ed, McGraw-Hill International, New York.

Dessler, Gary, 1997, Manajemen Sumberdaya Manusia. PT. Prenhallindo, Jakarta.

Handoko, T. Hani, 1999, Manajemen Personalia dan Sumber Daya Manusia, Edisi Kedua, BPFE Yogjakarta.

Hasibuan, Malayu Sultan Parlagutan, 1996, Organisasi dan Motivasi, Dasar Peningkatan Produktivitas, Bumi Aksara, Cetakan Pertama, Jakarta.

Listianto, Tony dan Setiaji, Bambang, Pengaruh Motivasi, Kepuasan, dan Disiplin Kerja Terhadap Kinerja Karyawan (Studi Kasus di Lingkungan Pegawai Kantor PDAM Kota Surakarta): Tesis, 2004, PPS Universitas Muhammadiyah Surakarta, Surakarta.

Mangkunegara, A. P. 2001. Manajemen Sumber Daya Manusia Perusahaan (Cetakan Ketiga). PT. Remaja Rosdakarya Offset. Bandung.

Miles, Matthew dan Huberman, Michael,1992, Analisa Data Kualitatif, Universitas Indonesia Press, Jakarta.

Prawirosentono, Suyadi. 1999. Analisis Kinerja Organisasi. PT. Rineka Cipta. Bandung.

Stone, Raymond J., 2005. Human Resources Management, John Wiley and Sons Australia, Ltd, Sydney.

Stroink, F.A.M., Pemahaman tentang Dekonsentrasi (diterjemahkan oleh: Prof. Dr. H. Ateng Syafrudin, SH), PT. Refika Aditama, Bandung

\section{Perundang-Undangan}


Undang-undang Nomor 43 Tahun 1999 tentang Pokok Pokok Kepegawaian.

Undang-Undang No 32 Tahun 2004 Tentang Pemerintahan Daerah

Peraturan Pemerintah No 30 Tahun 1980 Tentang Peraturan Disiplin Pegawai Negeri.

Peraturan Pemerintah No 97/2000 tentang Formasi Pegawai Negeri Sipil

Peraturan Menteri Pendayagunaan Aparatur Negara Nomor Per/09/M.PAN/05/2007 Tentang

Pedoman Umum Penetapan Indikator Kinerja Utama Di Lingkungan Instansi Pemerintah.

Keputusan Menteri Pendayagunaan Aparatur Negara Nomor: KEP/ 61/M.PAN/6/2004

Tentang Pedoman Pelaksanaan Analisis Jabatan

Perda Kota Bandar Lampung Nomor 4 Tahun 2009 tentang Perubahan atas Peraturan Daerah Nomor 2 Tahun 2008 tentang Organisasi dan Tata Kerja secretariat Daerah Kota, Sekretariat Daerah Kota, Sekretariat Dewan Perwakilan Perwakilan Rakyat Daerah Kota dan Staf Ahli Walikota Bandar Lampung.

Perda Kota Bandar Lampung Nomor 5 Tahun 2009 tentang Perubahan Atas Perda Nomor 3 Tahun 2008 tentang Organisasi dan Tata Kerja Dinas Daerah Kota Bandar Lampung 